\title{
Study on Relationship between DAK Forestry Program and GHG Reduction Target in Indonesia
}

\author{
Joko Tri Haryanto \\ Center for Climate Change Financing and Multilateral Policies, \\ Fiscal Policy Agency, Ministry of Finance, Indonesia \\ Djohar78@fiskal.depkeu.go.id
}

\begin{abstract}
It has been agreed that forestry is a key sector in the effort to tackle global warming. The government has demonstrated actual commitment to reduce GHG emissions by $26 \%$ with their own budget and by $41 \%$ with international financing. This commitment is set forth in Presidential Decree No. 61 Year 2011. This regulation indicates that one of the largest emitters is the forestry sector. The government has already allocated Specific Allocation Fund (DAK) Forestry in the State Budget annually to support forest rehabilitation. Despite the relatively small amount, the fund allocation is increasing significantly each year. The question is how the allocation for DAK Forestry can be synchronized with the GHG emission reduction target set forth in Presidential Decree No. 61 of 2011. For that reason, this study has been conducted in order to analyze the conformity of DAK Forestry funding with the emission reduction targets set forth in Presidential Decree No. 61 of 2011. By using qualitative descriptive statistical approach, it is known that the use of DAK Forestry fund as from 2010 to 2014 has had a significant alignment in support of GHG emission reduction target set forth in Presidential Decree No. 61 of 2011.
\end{abstract}

Keywords: DAK Forestry, forestry sector, GHG emission, Gov Regulation Number 61 Year 2011

\section{Introduction}

Wibowo, 2013, mentions that the forestry sector is still among the largest emitters in the increasing national emission of Green House Gasses (GHG) due to deforestation, forest degradation and forest fire. In the research conducted by Siswiyanti et al. (2015), deforestation and degradation are considered as the indicators of success and failure of forest management. For a long time, forestry has also become a significant object of international attention, especially when there is an increasing awareness of the importance of global environment quality. Another study conducted by Resosudarmo, 2005 indicate that even though it has become an object of global attention, political interest is unfortunately still used as the main consideration in making policies, in addition to the interest of global actors as well as global power discourses which often time lead to damage to natural resources and marginalization of people as well as weakening community cohesion. Today, most countries regard a $2^{0} \mathrm{C}$ temperature increase above preindustrial level as the maximum tolerable limit for global warming. An exceedance probability of below $20 \%$ for this limit implies an emission budget of less than $250 \mathrm{GtC}$ from 2000 to 2049, of which more than one third has already been emitted. Extrapolating current global CO2 emission this budget will only last until 2024 (Rickels, 2010).

In the short run period, green economy should be support achievement on the sustainable development through its indicator. Based on The Brudtland Commission Report of 1987, (World Commission on Environment and Development-WECD) brought the concept of sustainable development into politics. The follow up of the Brudtland Report, Agenda 21 introduced the concept of sustainable development indicators. According to Ajani (2013) a sustainable development indicator should provide condensed and neutral information about the state and development of an environmental or economic asset to the general public. Forest actually has highly significant impacts on climate condition (Astana et al., 2012). When the number of trees and plants decreases (due to deforestation), the amount of carbon dioxide absorbed in the atmosphere will also decrease. FAO (2005) as quoted in Astana et al. (2012) said that the rate of global forest loss is still very high, reaching 7.3 million ha per year in the period of 2000-2005. While the Forest Inventory and Mapping Center (2008) indicated that the rate of deforestation in Indonesia reached 1.87 million ha during the period of 1990-1996, and increased to 3.51 million ha during the period of 1996-2000 (Astana et al., 
2012). On the other hand, in 2009, President Susilo Bambang Yoedoyono (SBY) conveyed his commitment to decrease the national and regional GHG emission by $26 \%$ with the country's own budget (BAU) and by $41 \%$ with international financial aid. President SBY's commitment has been set out in Presidential Regulation Number 61 of 2011 regarding National Action Plan for the Reduction of GHG Emission (RAN/RAD-GRK).

The aforementioned regulation basically contains the outline of measures for the reduction of GHG emission including measures to be taken in the forestry sector, as well as the funding mechanism (Wibowo, 2013). In order to support measurable, reportable and verifiable measures for the reduction of GHG emission, the government has subsequently developed a method for the calculation of emission which was issued officially by IPCC (International Panel on Climate Change). With regard to financing, Presidential Regulation Number 61 of 2011 mandates the allocation of fund in the State/Regional Budget for financing RAN/RAD GRK activities, in addition to other potential sources from the private sector with due observance of applicable laws and regulations. In relation to the aforementioned mandate, the role of the State/Regional Budget in financing sectoral activities, especially in the forestry sector, may be implemented by using the budgeting mechanism of Technical Ministries/Agencies on annual basis or the mechanism of budget transfer to regions, particularly the Specific Allocation Fund (DAK) for Forestry (Fitri et al., 2011). If the financing is implemented by using the budgeting mechanism of Technical Ministries/Agencies, it must certainly be harmonized with the Government Work Plan (RKP) which refers to the National Medium Term Development Plan (RPJMN) and National Long Term Development Plan (RPJPN). The vision and mission of the President-elect are certainly regarded as additional considerations. During the presidency of President Jokowi, for example, his vision and mission set forth in Nawacita have certainly been used as one of the references in the preparation of the 2016 Government Work Plan.

On contrary, if the financing mechanism used is the regime of Transfer to Regions, it must certainly be synchronized with the provision of Law Number 33 of 2004 regarding Financial Balance Between the Central and Regional Governments as well as Government Regulation Number 55 Year 2005 regarding Balancing Funds. The problem is that both of the aforementioned financing mechanisms, either the budgeting of Ministries/Agencies or DAK Forestry, must be synchronized with the authorities set out in the government programs and policies. Accordingly, it is necessary to ensure synergy between the programs and the financing mechanism, in order to avoid financing overlap. Financing through Ministry/Agency should be used for financing the implementation of authorities which are at the level of Central Government, whereas financing with DAK Forestry should be used for financing the implementation of authorities that have been delegated to regions. Considering the significance of such matter, this study was conducted in order to find out the programs that have been mapped in Presidential Regulation Number 61 of 2011 and subsequently to compare them with activities that have been financed by DAK for Forestry from 2010 to 2014; which programs that are included in Presidential Regulation Number 61 of 2011 and have received fund allocation from DAK Forestry, as well as which programs that are beyond the reach of DAK Forestry. By mapping those programs, the objective of avoiding financing overlapping is expected to be reached.

This study also involved an analysis of the potentials of DAK financing by considering the provisions set forth in Law Number 33 of 2004 concerning Financial Balance between the Central Government and Regional Government, as well as the implementing regulations thereof, such as Regulations of the Minister of Finance related to the allocation of DAK fund from 2010 to 2014. Analysis of the allocation of DAK for Forestry in this study was limited to analysis of programs included in the technical guidelines and implementing regulations set forth in Regulations of the Minister of Forestry. More in-depth analysis cannot be conducted due to the limited data obtained from the Ministry of Forestry and Environment as the party responsible for DAK Forestry.

\section{Literature Review}

History of Forest Management in Indonesia: Riyanto (2006) said that environmental management policies have never been separated from political condition occurring in the society. It has also been case with forest management in Indonesia. Before independence, teakwood was exploited in Java for the construction of ships, barrels and chests, wooden parts of guns, carpentry and furniture. However, those forest products were only 
used for domestic needs of the colonial rulers and were not traded in international markets. While by using its power, VOC issued the first environmental policy for its colonial regions, namely prohibition to cut down trees without permit, in 1620 and followed by the imposition of taxes on wood and other forest products. Still according to Riyanto, 2006, during the transition to the application of governmental system known as Leaded Democracy, there were significant administrative changes in the forest management system. During the emergency government administration of Djuanda Cabinet, Indonesia issued Law Number 58 of 1958 stipulating that forest management shall be administered by level I autonomous regional government, except in Eastern Indonesia where it was to be administered by level II autonomous regional government. Such management system ended in 1960 when Indonesia issued Law Number 5 of 1960 regarding Principle Provisions on Agrarian Affairs setting forth that the State shall have the authorities for the management of agrarian resources, including land, water, forests, mining materials and air.

For such purpose, the government stipulated in 1961 that the authority to manage all forests in Indonesia was to be held centrally by State-owned Forestry Company, Perusahaan Kehutanan Negara (Perhutani), which supervised 13 working units, and placed Perhutani as the regulator. During this period, there was an apparent shift in the orientation of forest management towards the ongoing development activities. Perhutani as the central institution regulating the forestry sector, started its activities to exploit wood in regions in cooperation with foreign companies. During the New Order era, according to Kartodihardjo and Jhamtani (2006), forest management was aimed at three new points of orientation, namely: 1) economic policy for implementing national development; 2) involvement of military elements in the elites managing the forestry sector; and 3) reduction of the role of community organizations in forest management without civil supervision and intervention. With the orientation on national development and economic advancement, the government subsequently formulated Law Number 5 of 1967 regarding the Basic Principles of Forestry as the basic regulation on the harvesting of forest products.

Legal framework was applied by issuing Government Regulations, such as GR No 21 of 1970 regarding the Issuance of Forest Concessions (HPH) and Forest Product Harvesting Concessions (HPHH) and GR Number 33 of 1970 regarding Forest Planning. During the period following the formulation of such legal framework on forest exploitation, there was massive deforestation which will be used here as the basic problem. Kartodihardjo and Jhamtani (2006) also said mentioned about forest management during the 1997 monetary crisis, which was marked by weakening political stability in Indonesia. Such condition led to significant political changes, especially with regard to the management of the forestry sector. As a political force, civil society was able to convey their aspirations regarding traditional community forests which were increasingly exploited due to the rationalization of the existing legal framework. Forest management by the government which was driven by economic targets resulted in the increasing rate of deforestation. Accordingly, the government issued GR Number 6 of 1999 in place of GR Number 21 of 1970 and Law Number 41 of 1999 regarding Basic Principles of Forestry for regulating forest management so as to be more accommodative for the general public.

Problems in Forest Management in Indonesia: Indonesia is the third largest country with the largest tropical forests in the world and ranks the first in the Asia Pacific. Indonesia is one of the largest contributors of carbon for the world. Indonesian tropical rain forests occupy $\pm 1,148,400$ square kilometers with extensive biological diversity. Unfortunately, Indonesia is also among the countries with the highest rates of deforestation and forest degradation in the world (Ekawati et al., 2013). Forest destruction in Indonesia does not occur only in production forests but also in protected and conservation forests (natural conservations, animal conservations, natural tourism parks, game hunting parks). The decreasing size of forest areas caused by the increasing needs the surrounding communities, the dependence of the surrounding communities on forests, illegal logging, lack of awareness regarding the functions and benefits of forests, as well as the conversion of forests into agricultural fields, mining areas, and plantations has led to the increasing size of critical lands within and outside forest areas. Currently, various efforts have been made to address the issue of critical lands with various programs and financing models by the central government, regional governments and donors. However, those efforts have not been effective due to imbalances in the implementation of critical land rehabilitation programs (Rickels, 2010). 
Critical lands are occurring in Indonesia with increasing rate each year. It is caused by the increasing rate of land conversion as well as the high level of illegal logging within and outside forest areas for the creation of new areas for settlement, plantation, and agricultural activities. According to data in 2013, critical lands in Indonesia reached 133 million hectares, comprising potential critical lands of $47.55 \%$, slightly critical lands of $34,28 \%$, critical lands of $14.62 \%$ highly critical lands of 3.55\% (KLHK, 2013). The high occurrence rate of critical land greatly affects the increasing rate of deforestation and global climate change. As a country with complex biological diversity, Indonesia has a strategic role in addressing such problems. Various efforts and policies related to the handling of critical lands have been made for a long period of time. However, the fact is that such efforts and policies have not been implemented optimally and thus far they are still partial in nature (Susiyanto, 2015). The government has set a target for emission reduction by 31.15 million tons of $\mathrm{CO}^{2}$ in the National Action Plan for Green House Gas Emission Reduction (RAN-GRK). However, in order to achieve such target, there have been many obstacles encountered in rehabilitating critical lands in Indonesia, such as: weak political support from regional governments, unclear working mechanism among government agencies overseeing the forestry sector, as well as tenure and funding problems. Sectoral policies on the handling of critical lands need to be changed in order to ensure coordinated and effective management of the efforts. Participation of all parties and all ministries/agencies is required for decreasing the rate of occurrence of critical lands and for restoring the function of the lands by way of land rehabilitation to ensure that the land can sustain its physical, chemical or biological functions. Therefore, the hydrological, hydroorological, agricultural, settlement as well as social and economic functions of the surrounding areas will not be compromised because the ecological balance can be maintained (Diniyati \& Awang, 2010).

DAK Forestry for RAD GRK: Pursuant to Law Number 33 of 2004 regarding Financial Balance Between the Central Government and Regional Governments, it can be concluded that DAK Forestry is fund originating from the State Budget allocated for regions having forest areas for helping those areas in financing RAD GRK programs, especially in the forestry sector. This is because RAD GRK is part of the mandatory regional affairs for managing the environmental function and it is also a national priority. The aforementioned conclusion has actually been implied in the background section of Regulation of the Minister of Forestry No. P.47/MenhutII/2012 regarding technical guidelines on the use of specific allocation fund (DAK) for forestry sector in the fiscal year of 2013. In the background section of the aforementioned regulation, the Minister of Forestry mentioned as follows:

One of the efforts to address the problems of climate change and global warming is by planting more trees and plants. Therefore, in order to preserve the existing forests so as to be functioning well, it is necessary to conduct Forest and Land Rehabilitation (RHL) activities, in addition to preventing activities causing forest destruction. Currently there are 27.2 million hectares of critical lands that need to be rehabilitated immediately (Directorate General of BPDASPS, 2011). The Ministry of Forestry places RHL as one of the national priority policies. This policy is very relevant for addressing the problems encountered by regions (Provinces and Regencies/Cities) in relation to the increasingly degraded environment, including forest and land destruction, as well as decreasing quality of the environment that may lead to flood, landslide, high rate of abrasion, sea water intrusion as well as global warming. Based on Government Regulation Number 55 of 2005 regarding Balancing Funds, Forest and Land Rehabilitation as well as its supporting activities which constitute the authority of regional government, may be financed with funds from the Ministry of Forestry's portion of the State Budget by using the Specific Allocation Fund (DAK) for the forestry sector. Considering the limited amount of DAK Forestry (and DAK Environment), the Government faces increasing demand for selecting the most efficient and effective forestry activities in order to achieve the priority targets in environmental management.

The obligation to allocate DAK for the most efficient and effective activities is set forth in Government Regulation No. 21 of 2004 regarding Preparation of Work Plan and Budget of State Ministries/Agencies. This regulation requires Ministries/Government Agencies to prepare performance-based (expenditures) budget. DAK is one of the expenditures for which Ministries/Government Agencies are responsible. Article 7 of the aforementioned Government Regulation specifies that the preparation of performance-based budget is to be conducted by taking into account the relations between the financing and the expected outputs of the activities, including efficiency with regard to the achievement of the aforementioned results and outputs. The 
output is in the form of goods and services produced by activities implemented for supporting the effort for achieving the targets and objectives of the program and policies. Whereas the outcome is anything reflecting the functioning of output from activities in a program. The preparation of performance-based budget requires performance indicators, cost standard, and performance evaluation for every program and every type of activity. The level of activity planned and cost standard determined in the beginning of the annual cycle of budgeting serve as the basis for determining the budget for the relevant budget year and prognostication for the relevant programs (Setiono, 2013).

\section{Methodology}

In general, this study applies descriptive qualitative approach by analyzing the comparison of programs set forth in Presidential Regulation Number 61 of 2011 with programs financed with DAK Forestry as from 2010 to 2014. Evaluation of programs financed by DAK Forestry was based on the Technical Guidelines on the allocation of DAK Forestry issued by the Ministry of Forestry and Environment (KLHK). The reference of the Technical Guideline of DAK Forestry is Regulation of the Minister of Forestry regarding Technical Guidelines and Implementing Guidelines on the Allocation of DAK Forestry for the Year 2010 up to 2014. Whereas program evaluation as intended in Presidential Regulation No 61 of 2011 is conducted by referring to various programs listed in the attachment to Presidential regulation No 61 of 2011. The type of data used were mostly secondary data obtained from various official sources, including the Ministry of Finance for data of Balancing Fund allocations (DBH, DAU and DAK), Bappenas in relation to Presidential Regulation Number 61 of 2011, as well as the Ministry of Forestry in relation to Regulation of the Minister of Forestry (Permenhut) used as the basis of the technical guidelines on the allocation of DAK Forestry. The method of analysis used was literature comparative study by mapping various programs listed in Presidential Regulation Number 61 of 2011. Based on the results of the mapping, an analysis was subsequently conducted on the programs listed in the Technical Guidelines on DAK Forestry for 2010 up to 2014, for subsequently conducting overlay of policies related to which programs are recommended to be financed with DAK Forestry and which programs are beyond the reach of DAK Forestry. Analysis was also conducted on Law Number 23 of 2014 regarding Regional Government in order to find an overview of the distribution of authorities in the forestry sector.

\section{Results and Analysis}

Analysis of Potential DAK Financing: In order to support the implementation of fiscal decentralization, the government has allocated budget for each programs in the mechanism of Transfer to Regions consistently with increasingly larger amount allocated each year. The amounts of budget allocations for each program are described in detail in Figure 1.

Figure 1: Transfer to Regions

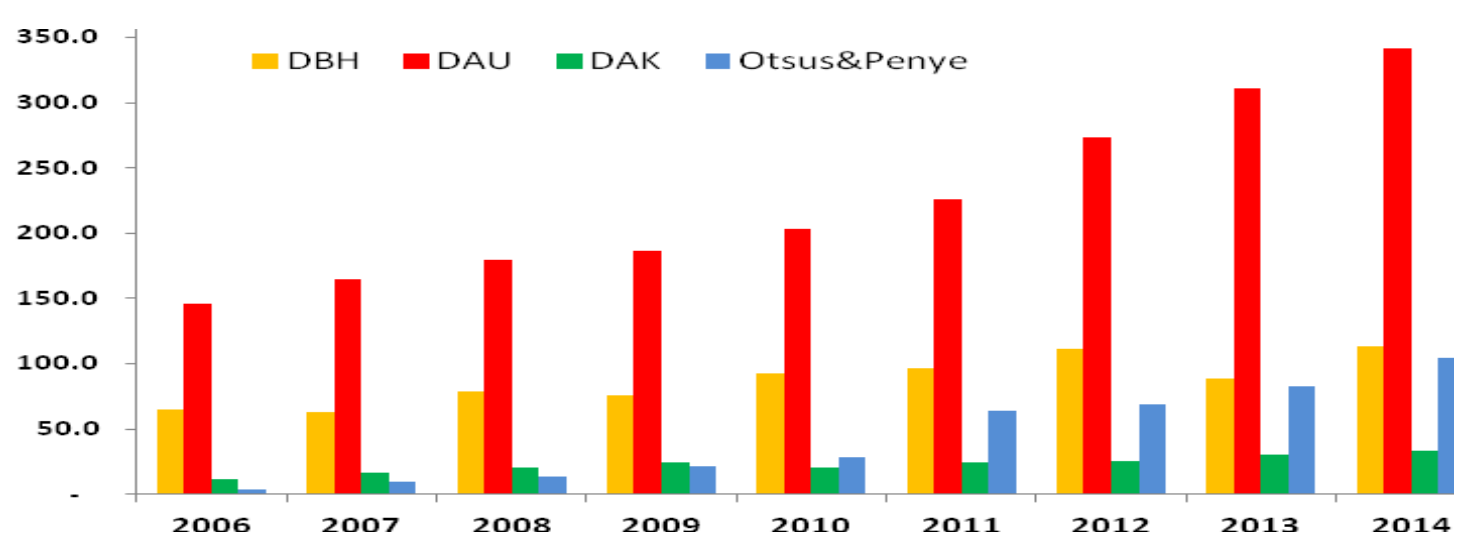

Source: Haryanto, 2014 
As shown in Figure 1, General Allocation Fund (DAU) allocation has always become the largest contributor to Balancing Funds each year. If in 2006 the amount was still around Rp145.6 trillion, it increased to Rp225.5 trillion in 2011 and Rp341.2 trillion in 2014. Whereas Profit Sharing Fund (DBH) has been the next largest component. Similar to DAU mechanism, DBH is a mechanism of funding which is in the form of block grant and general in nature. DBH allocation comprises DBH Taxes and DBH Natural Resources. While DAU allocation is based on a formula, DBH is allocated based on the realization of budget calculation. Compared to DAU and DBH, allocation for DAK is relatively small among the components of Balancing Fund. However, as from 2006 to 2014, its amount is increasing persistently. For example, in 2006, its amount was still around Rp11.5 trillion, but in 2011 it soared to Rp24.8 trillion and Rp33.0 trillion in 2014. Compared to DAU and DBH mechanisms, DAK has an advantage namely that it must be used only for physical development. This has also decreased potential misappropriation or abuse for activities that are not related to its main purpose. In its further development, the sectors receiving DAK allocation are continuously increasing. In 2006, DAK was still limited to allocation of fund for nine sectors (education, health, road, irrigation, drinking water, government infrastructure, marine and fishery, agriculture and environment), but in 2011, the number increased to 19 sectors. Forestry has been among those 19 sectors receiving DAK allocation. Data of DAK allocation from 2010 to 2014 is presented in Table 1.

Table 1: DAK Allocations in 2010 - 2014 (Rp Billion)

\begin{tabular}{|c|c|c|c|c|c|}
\hline Sector & 2010 & 2011 & 2012 & 2013 & 2014 \\
\hline Education & 9,334 & 10,041 & 10,041 & 11,09 & 10,041 \\
\hline Health & 2,829 & 3,000 & 3,005 & 3,101 & 3,129 \\
\hline Road & 2,810 & 3,900 & 4,012 & 5,373 & 6,105 \\
\hline Irrigation & 968 & 1,311 & 1,348 & 1,614 & 2,289 \\
\hline Govt. Infrastructure & 386 & 400 & 444 & 481 & 499 \\
\hline Marine \& Fishery & 1,207 & 1,500 & 1,547 & 1,812 & 1,851 \\
\hline Drinking Water & 357 & 419 & 502 & 609 & 885 \\
\hline Agriculture & 1,543 & 1,806 & 1,879 & 2,542 & 2,579 \\
\hline Environment & 351 & 400 & 479 & 530 & 548 \\
\hline Demographic Affairs & 329 & 368 & 392 & 442 & 462 \\
\hline Forestry & 250 & 400 & 489 & 539 & 558 \\
\hline Rural Facilities \& Infrastructure & 300 & 315 & 356 & 717 & 754 \\
\hline Trade & 107 & 300 & 345 & 694 & 731 \\
\hline Sanitation & 357 & 419 & 463 & 569 & 829 \\
\hline Rural Electricity & 0 & 150 & 190 & 432 & 467 \\
\hline Housing \& Settlement & 0 & 150 & 191 & 205 & 234 \\
\hline Land Transportation Safety & 0 & 100 & 131 & 221 & 235 \\
\hline Rural Transportation & 0 & 150 & 171 & 260 & 301 \\
\hline $\begin{array}{l}\text { Border Areas Facilities \& } \\
\text { Infrastructure }\end{array}$ & 0 & 100 & 121 & 458 & 493 \\
\hline
\end{tabular}

Source: Ministry of Finance, 2014

Upon analysis, data in Table 1 indicates that allocation for DAK Forestry, despite the small amount compared to allocations for education, health, infrastructure, marine and fishery as well as agriculture, has been continuously increasing. Such support should be used as reinforcement for the Government's efforts and commitment to reduce the national GHG emission under Presidential Regulation Number 61 of 2011, considering that such regulation is a form of policy and target for actual actions for supporting the reduction of emission by $26 \%$ and $41 \%$ in 2020 (Wibowo, 2013). Unfortunately, the allocation for DAK Forestry philosophically places reforestation and replanting of critical lands in higher priorities. The allocation for 
DAK Forestry has not been prioritized for regions having high level of forest conservation. As a consequence, some parties consider the mechanism of DAK Forestry provides incentive for regions for conducting deforestation and forest degradation in order to obtain larger allocation. Whereas regions with high level of conservation do not obtain adequate allocation. For that reason, it is necessary to increase the priority of DAK Forestry allocation for regions having relatively high level conservation in the future.

Evaluation of Programs Listed in Presidential Regulation Number 61 of 2011: In general, Presidential Regulation Number 61 of 2011 has been used as the legal basis applicable at the national and regional levels for the reduction of GHG emission in Indonesia. The GHG reduction program itself comprises core and supporting activities. There are five sectors considered as the largest sources of emission in Presidential Regulation Number 61 of 2011 namely: forestry/agriculture and peatland, energy, transportation, waste management and industry. In its implementation, RAN/RAD GRK documents have the function as guidelines for the relevant Ministries/Agencies as well as Regional Governments in the planning of GHG emission reduction. In relation to the forestry sector, analysis can be conducted on the types of policies implemented for supporting the program, namely:

a) Reduction of GHG emission which at the same time increases the peacefulness of the environment, prevents disasters, absorbs manpower and increases the people's and state's income;

b) Management of water network systems and water management in swamp areas;

c) Maintenance of swamp reclamation networks (including the existing peatland);

d) Improvement of the productivity and production efficiency of agriculture in swamp land with the lowest emission possible and absorbing carbon dioxide optimally.

Whereas the strategies applied were as follows:

a) Reducing the rate of deforestation and forest degradation for reducing GHG emission;

b) Increasing the planting of trees for absorbing GHG emission;

c) Enhancing the measures for forest protection against forest fire and illegal logging as well as applying Sustainable Forest Management (SMF);

d) Rehabilitating water systems (networks) and dividing blocks as well as stabilizing the elevation of water surface in swamp water networks;

e) Optimizing land and water resources without conducting deforestation;

f) Applying land management and agricultural cultivation technologies with the lowest possible GHG emission and ability to absorb carbon dioxide optimally.

Based on the above description of policies and strategies, a list was subsequently made containing core and supporting programs and activities as well as the parties in charge of them. Description of the programs and activities in the forestry sector in Presidential Regulation Number 61 of 2011 is presented in Table 2;

Table 2: Forestry Programs and Activities in Presidential Regulation 61/2011

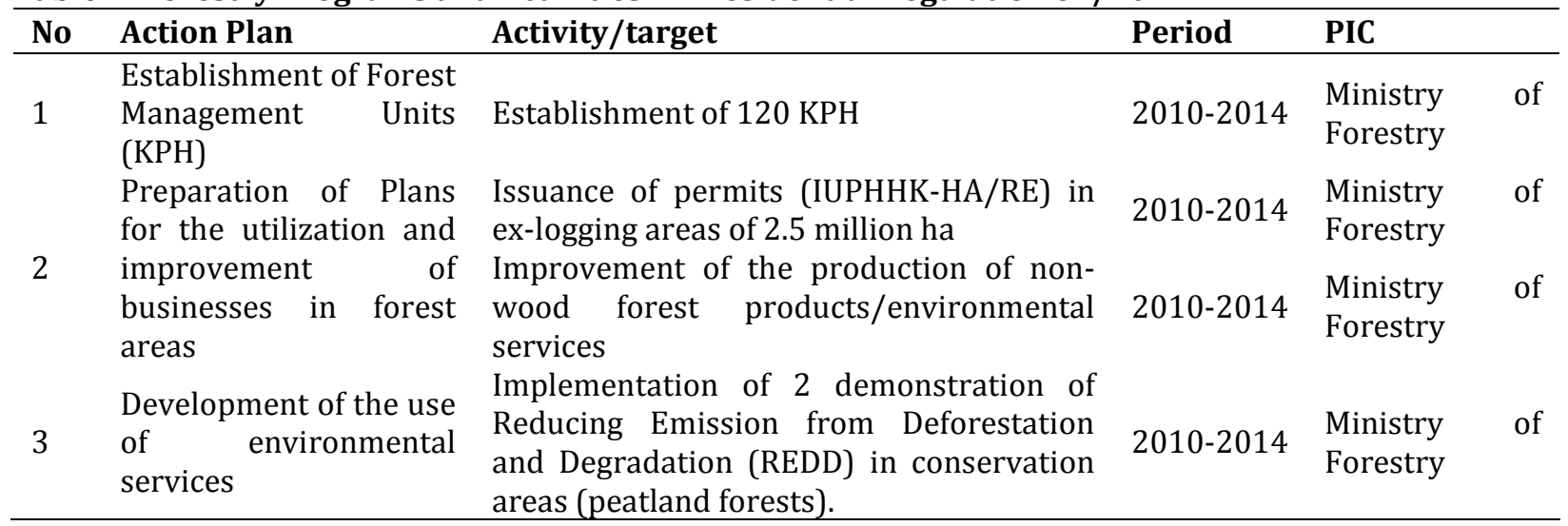




\begin{tabular}{|c|c|c|c|c|c|}
\hline 4 & $\begin{array}{l}\text { Confirmation of forest } \\
\text { areas }\end{array}$ & $\begin{array}{l}\text { Implementation of the arrangement of } \\
\text { Forest Area Borders (exterior borders and } \\
\text { borders of areas functioning as forest } \\
\text { areas) of } 25,000 \mathrm{~km}\end{array}$ & $2010-2014$ & $\begin{array}{l}\text { Ministry } \\
\text { Forestry }\end{array}$ & of \\
\hline 5 & $\begin{array}{l}\text { Improvement, } \\
\text { rehabilitation, } \\
\text { operation, and } \\
\text { maintenance of swamp } \\
\text { reclamation networks }\end{array}$ & $\begin{array}{l}\text { Improvement of swamp reclamation } \\
\text { networks of } 10,000 \text { ha, rehabilitation of } \\
\text { swamp reclamation networks of } 450,000 \\
\text { ha, operation \& maintenance reclamation } \\
\text { of } 1.2 \text { million ha of swamps }\end{array}$ & $2010-2014$ & $\begin{array}{l}\text { Ministry } \\
\text { Public Works }\end{array}$ & of \\
\hline 6 & $\begin{array}{l}\text { Management of } \\
\text { peatland, for } \\
\text { sustainable agriculture }\end{array}$ & $\begin{array}{l}\text { Studies on and development of land } \\
\text { resources (including peatland) for the } \\
\text { development of the management of } \\
\text { agricultural land of } 325,000 \text { ha }\end{array}$ & $2011-2014$ & $\begin{array}{l}\text { Ministry } \\
\text { Agriculture }\end{array}$ & of \\
\hline 7 & $\begin{array}{l}\text { Management } \\
\text { agricultural land in } \\
\text { abandoned } \\
\text { degraded peatland in } \\
\text { order to support the } \\
\text { plantation, animal } \\
\text { farming } \\
\text { horticulture } \\
\text { sectors }\end{array}$ & $\begin{array}{l}\text { Rehabilitation, reclamation and } \\
\text { revitalization of abandoned and degraded } \\
\text { peatland, in agricultural areas, as well as } \\
\text { optimization of non-food crop land of } \\
250,000 \text { ha }\end{array}$ & $2011-2014$ & $\begin{array}{l}\text { Ministry } \\
\text { Agriculture }\end{array}$ & of \\
\hline \multirow{4}{*}{8} & \multirow{4}{*}{$\begin{array}{l}\text { Implementation of } \\
\text { forest and land } \\
\text { rehabilitation, and } \\
\text { forest reclamation in } \\
\text { priority River Basins }\end{array}$} & $\begin{array}{l}\text { Implementation of forest rehabilitation in } \\
\text { priority River Basins of } 500,000 \text { ha }\end{array}$ & $2010-2014$ & $\begin{array}{l}\text { Ministry } \\
\text { Forestry }\end{array}$ & of \\
\hline & & $\begin{array}{l}\text { Implementation of critical land } \\
\text { rehabilitation in priority River Basins of } \\
1,954,000 \text { ha }\end{array}$ & $2010-2014$ & $\begin{array}{l}\text { Ministry } \\
\text { Forestry }\end{array}$ & of \\
\hline & & Development of city forests of 6,000 ha & $2010-2014$ & $\begin{array}{l}\text { Ministry } \\
\text { Forestry }\end{array}$ & of \\
\hline & & $\begin{array}{l}\text { Rehabilitation of mangrove forests/coastal } \\
\text { forests of } 40,000 \text { ha }\end{array}$ & $2010-2014$ & $\begin{array}{l}\text { Ministry } \\
\text { Forestry }\end{array}$ & of \\
\hline \multirow{2}{*}{9} & \multirow{2}{*}{$\begin{array}{l}\text { Development of social } \\
\text { forestry }\end{array}$} & $\begin{array}{l}\text { Facilitation of the determination of Social } \\
\text { Forest/Village Forest management } \\
\text { working areas of } 2,500,000 \text { ha }\end{array}$ & $2010-2014$ & $\begin{array}{l}\text { Ministry } \\
\text { Forestry }\end{array}$ & of \\
\hline & & $\begin{array}{l}\text { Facilitation of the establishment of } \\
\text { business partnership in private forests of } \\
250,000 \text { ha }\end{array}$ & $2010-2014$ & $\begin{array}{l}\text { Ministry } \\
\text { Forestry }\end{array}$ & of \\
\hline 10 & Control of forest fire & $\begin{array}{l}\text { Achievement of decrease in the number of } \\
\text { hotspots in Kalimantan, Sumatra, and } \\
\text { Sulawesi by } 20 \% \text { annually from the } \\
\text { average of } 2005-2009 \text {, with success rate of } \\
67.20 \%\end{array}$ & $2010-2014$ & $\begin{array}{l}\text { Ministry } \\
\text { Forestry }\end{array}$ & of \\
\hline 11 & $\begin{array}{l}\text { Investigation and } \\
\text { safeguarding of forests }\end{array}$ & $\begin{array}{l}\text { Completion of the handling of new cases of } \\
\text { forestry crimes (illegal logging, illegal } \\
\text { mining and fire) at least by } 75 \%\end{array}$ & $2010-2014$ & $\begin{array}{l}\text { Ministry } \\
\text { Forestry }\end{array}$ & of \\
\hline \multirow{2}{*}{12} & $\begin{array}{l}\text { Development of } \\
\text { conservation areas, }\end{array}$ & $\begin{array}{l}\text { Improvement in the management of } \\
\text { essential ecosystems as ecological life } \\
\text { support system by } 10 \%\end{array}$ & $2010-2014$ & $\begin{array}{l}\text { Ministry } \\
\text { Forestry }\end{array}$ & of \\
\hline & $\begin{array}{l}\text { and development of } \\
\text { protected forests }\end{array}$ & $\begin{array}{l}\text { Implementation of the handling of } \\
\text { conservation forest and protected forest } \\
\text { encroachment in } 12 \text { priority provinces }\end{array}$ & $2010-2014$ & $\begin{array}{l}\text { Ministry } \\
\text { Forestry }\end{array}$ & of \\
\hline
\end{tabular}




\begin{tabular}{llllll}
\hline 13 & $\begin{array}{l}\text { Improvement } \begin{array}{l}\text { of } \\
\text { plantation } \\
\text { business }\end{array} \\
\text { forest }\end{array}$ & $\begin{array}{l}\text { Allocation of areas for industrial } \\
\text { plantation forests and people's plantation } \\
\text { forests (HTI/HTR) of 3 million ha }\end{array}$ & 2010-2014 & $\begin{array}{l}\text { Ministry } \\
\text { Forestry }\end{array}$ & of \\
\hline
\end{tabular}

Source: Setiono, 2013

Evaluation of Programs in DAK Forestry: The Ministry of Forestry issues Regulations of the Minister of Forestry every year as technical guidelines on the use of DAK for the Forestry Sector. The analysis of Technical Guidelines on DAK Forestry by year of issuance is as follows:

DAK Forestry in 2010: DAK Forestry for the fiscal year 2010 was allocated based on Regulation of the Minister of Forestry Number: P.03/Menhut-II/2010 regarding Technical Guidelines on the Use of Specific Allocation Fund for the Forestry Sector in Fiscal Year 2010. Pursuant to the aforementioned regulation, DAK Forestry of 2010 was to be used for the following activities:

a) Rehabilitation of Critical Land on River Basins;

b) Rehabilitation of Swamp, Peatland, Mangrove and Coastal Forests;

c) Development of Forestry Counseling Facilities and Infrastructure;

d) Development of Forest Safeguarding Facilities and Infrastructure;

e) Development of Facilities and Infrastructure for the Management of Forest Conservation Parks (Taman Hutan Raya/Tahura).

Upon conducting overlay of policies set forth in Presidential Regulation Number 61 of 2011, out of the five aspects of the use of DAK Forestry in 2010, only the uses mentioned in point three (Development of Forestry Counseling Facilities and Infrastructure) and point five (Development of Facilities and Infrastructure for the Management of Forest Conservation Parks) are not directly related to the list of activities for the GHG emission reduction. Whereas the other four uses are directly related to the GHG emission reduction program as intended in Presidential Regulation Number 61 of 2011. The matrix of interconnection of those programs is presented in Table 3.

Table 3: Intersection of Activities and Programs between Presidential Regulation and DAK Forestry of 2010

\begin{tabular}{|c|c|c|c|}
\hline No & $\begin{array}{l}\text { Action Plan in } \\
\text { Presidential } \\
\text { Regulation }\end{array}$ & Activity/Target & DAK Forestry \\
\hline 1 & $\begin{array}{l}\text { Implementation of } \\
\text { forest and land } \\
\text { rehabilitation, and } \\
\text { forest reclamation } \\
\text { in priority River } \\
\text { Basins }\end{array}$ & $\begin{array}{l}\text { Implementation of forest rehabilitation in } \\
\text { priority River Basins of } 500,000 \text { ha } \\
\text { Implementation of critical land rehabilitation in } \\
\text { priority River Basins of } 1,954,000 \text { ha } \\
\text { Development of city forests of } 6,000 \text { ha } \\
\text { Rehabilitation of mangrove forests/coastal } \\
\text { forests of } 40,000 \text { ha }\end{array}$ & $\begin{array}{l}\text { Rehabilitation of critical } \\
\text { land in River Basins } \\
\text { Rehabilitation of } \\
\text { Swamp, Peatland, } \\
\text { Mangrove and Coastal } \\
\text { Forests }\end{array}$ \\
\hline 2 & $\begin{array}{l}\text { Investigation } \\
\text { safeguarding } \\
\text { forests }\end{array}$ & $\begin{array}{l}\text { Completion of the handling of new cases of } \\
\text { forestry crimes (illegal logging, illegal mining } \\
\text { and fire) at least by } 75 \%\end{array}$ & $\begin{array}{l}\text { Development of Forest } \\
\text { Safeguarding Facilities } \\
\text { and Infrastructure }\end{array}$ \\
\hline
\end{tabular}

Source: Regulation of the Minister of Forestry, 2010, Perpres 61/2011

Table 4: Use of DAK Forestry of 2010

\begin{tabular}{lll}
\hline No & Use & Activity/Target \\
\hline & & Reforestation and vegetative enrichment \\
1 & $\begin{array}{l}\text { Rehabilitation of critical } \\
\text { land in River Basins }\end{array}$ & Tree planting
\end{tabular}




\begin{tabular}{|c|c|c|}
\hline & & Conservation of land and water \\
\hline 2 & $\begin{array}{l}\text { Rehabilitation of Mangrove } \\
\text { and Coastal Forests }\end{array}$ & $\begin{array}{l}\text { Aimed at reducing the impacts of disasters in coastal areas which is } \\
\text { conducted by referring to applicable criteria, guidelines, technical } \\
\text { guidelines on the implementation of activities especially those issued } \\
\text { by the Ministry of Forestry }\end{array}$ \\
\hline 3 & $\begin{array}{l}\text { Development of Forest } \\
\text { Safeguarding Facilities and } \\
\text { Infrastructure }\end{array}$ & $\begin{array}{l}\text { Implemented in accordance with the needs and budget availability by } \\
\text { referring to the standard, guidelines and technical guidelines on the } \\
\text { implementation of activities. Procurement of forest facilities and } \\
\text { infrastructure in the form of motorbikes, guard posts, GPS, } \\
\text { communication equipment }\end{array}$ \\
\hline
\end{tabular}

Source: Regulation of the Minister of Forestry, 2010

DAK Forestry of 2011: Whereas DAK Forestry for the fiscal year 2011 was allocated based on Regulation of the Minister of Forestry Number: P.03/Menhut-II/2011 regarding Technical Guidelines on the Use of Specific Allocation Fund for the Forestry Sector in Fiscal Year 2011. Pursuant to the aforementioned regulation, DAK Forestry of 2011 was to be used for the following activities:

a) Rehabilitation of Forest and Critical Land on Priority River Basins Hutan, including the Rehabilitation of Swamp, Peatland, Mangrove and Coastal Forests as well as tree planting activities;

b) Development of Forest Safeguarding Facilities and Infrastructure;

c) Development of Forestry Counseling Facilities and Infrastructure;

d) Development of Facilities and Infrastructure for the Management of Forest Conservation Parks (Taman Hutan Raya/Tahura).

In general, the direction of the policies and technical guidelines on the allocations of DAK Forestry of 2011 were relatively similar to the allocations of DAK Forestry of 2010. This means that the conformity of the programs to the policies set forth in Presidential Regulation Number 61 of 2011 is also relatively similar. The matrix of interconnection of those programs is presented in Table 5.

Table 5: Intersection of Activities and Programs between Presidential Regulation and DAK Forestry of 2011

\begin{tabular}{|c|c|c|c|}
\hline No & $\begin{array}{l}\text { Action Plan in } \\
\text { Presidential } \\
\text { Regulation }\end{array}$ & Activity/Target & DAK Forestry \\
\hline 1 & $\begin{array}{l}\text { Implementation of } \\
\text { forest and land } \\
\text { rehabilitation, and } \\
\text { forest reclamation } \\
\text { in priority River } \\
\text { Basins }\end{array}$ & $\begin{array}{l}\text { Implementation of forest rehabilitation in } \\
\text { priority River Basins of } 500,000 \text { ha } \\
\text { Implementation of critical land rehabilitation in } \\
\text { priority River Basins of } 1,954,000 \text { ha } \\
\text { Development of city forests of } 6,000 \text { ha } \\
\text { Rehabilitation of mangrove forests/coastal } \\
\text { forests of } 40,000 \text { ha }\end{array}$ & $\begin{array}{l}\text { Rehabilitation of critical } \\
\text { land in River Basins } \\
\text { Rehabilitation of } \\
\text { Swamp, Peatland, } \\
\text { Mangrove and Coastal } \\
\text { Forests }\end{array}$ \\
\hline 2 & $\begin{array}{l}\text { Investigation and } \\
\text { safeguarding of } \\
\text { forests }\end{array}$ & $\begin{array}{l}\text { Completion of the handling of new cases of } \\
\text { forestry crimes (illegal logging, illegal mining } \\
\text { and fire) at least by } 75 \%\end{array}$ & $\begin{array}{l}\text { Development of Forest } \\
\text { Safeguarding Facilities } \\
\text { and Infrastructure }\end{array}$ \\
\hline
\end{tabular}

Source: Regulation of the Minister of Forestry 2011, Perpres 61/ 2011

DAK Forestry of 2012: The allocation of DAK Forestry for fiscal year 2012 was based on Regulation of the Minister of Forestry Number: P.69/Menhut-II/2011 regarding Technical Guidelines on the Use of Specific Allocation Fund for the Forestry Sector in Fiscal Year 2012. Pursuant to the aforementioned regulation, DAK Forestry of 2012 was to be used for the following activities:

Rehabilitation of forest and critical land on priority River Basins including Rehabilitation of Swamp, Peatland, Mangrove and Coastal Forests as well as land rehabilitation programs. For provinces/regency/city having 
damaged mangrove forests, DAK Forestry program were to be prioritized for the rehabilitation of mangrove forests;

a) Development of Forest Safeguarding Facilities and Infrastructure;

b) Development of Forestry Counseling Facilities and Infrastructure;

c) Development of Facilities and Infrastructure for the Management of Forest Conservation Parks (Taman Hutan Raya/Tahura);

d) Development of KPH Operational Facilities and Infrastructure.

Table 6: Use of DAK Forestry of 2011

\begin{tabular}{|c|c|c|}
\hline No & USE & ACTIVITY/TARGET \\
\hline & & Reforestation and vegetative enrichment \\
\hline 1 & $\begin{array}{l}\text { Rehabilitation of critical } \\
\text { land in River Basins }\end{array}$ & Tree planting \\
\hline & & tion of land and water \\
\hline 2 & $\begin{array}{l}\text { Rehabilitation } r \text { of } \\
\text { Mangrove and Coastal } \\
\text { Forests }\end{array}$ & $\begin{array}{l}\text { Aimed at reducing the impacts of disasters in coastal areas which is } \\
\text { conducted by referring to applicable criteria, guidelines, technical } \\
\text { guidelines on the implementation of activities especially those } \\
\text { issued by the Ministry of Forestry }\end{array}$ \\
\hline 3 & $\begin{array}{l}\text { Development of Forest } \\
\text { Safeguarding Facilities } \\
\text { and Infrastructure }\end{array}$ & $\begin{array}{l}\text { Implemented in accordance with the needs and budget availability } \\
\text { by referring to the standard, guidelines and technical guidelines on } \\
\text { the implementation of activities. Procurement of forest facilities and } \\
\text { infrastructure in the form of motorbikes, guard posts, GPS, } \\
\text { communication equipment }\end{array}$ \\
\hline
\end{tabular}

Source: Regulation of the Minister of Forestry, 2011

There is slight difference in the allocation of DAK Forestry in 2012 whereby it was also used for the Development of KPH Operational Facilities and Infrastructure. This is the only difference between the allocation of DAK Forestry of 2012 and the allocations in 2010 and 2011. In relation to the programs set forth in Presidential Regulation Number 61 of 2011, the additional allocation for the development of KPH operational facilities and infrastructure actually adds to supported programs having intersection. The matrix of interconnection of those programs is presented in Table 7.

Table 7: Intersection of Activities and Programs between Presidential Regulation and DAK Forestry of 2012

\begin{tabular}{|c|c|c|c|}
\hline No & $\begin{array}{l}\text { Action Plan in } \\
\text { Presidential Regulation }\end{array}$ & Activity/Target & DAK Forestry \\
\hline 1 & $\begin{array}{l}\text { Development of Forest } \\
\text { Management Unit }(\mathrm{KPH})\end{array}$ & Establishment of $120 \mathrm{KPH}$ & $\begin{array}{l}\text { Development of } \mathrm{KPH} \\
\text { Operational Facilities and } \\
\text { Infrastructure }\end{array}$ \\
\hline 2 & $\begin{array}{l}\text { Implementation of forest } \\
\text { and land rehabilitation, and } \\
\text { forest reclamation in } \\
\text { priority River Basins }\end{array}$ & $\begin{array}{l}\text { Implementation of forest rehabilitation } \\
\text { in priority River Basins of } 500,000 \text { ha } \\
\text { Implementation of critical land } \\
\text { rehabilitation in priority River Basins of } \\
1,954,000 \text { ha } \\
\text { Development of city forests of } 6,000 \text { ha } \\
\text { Rehabilitation of mangrove } \\
\text { forests/coastal forests of } 40,000 \text { ha }\end{array}$ & $\begin{array}{l}\text { Rehabilitation of critical } \\
\text { land in River Basins } \\
\text { Rehabilitation of Swamp, } \\
\text { Peatland, Mangrove and } \\
\text { Coastal Forests }\end{array}$ \\
\hline 3 & $\begin{array}{l}\text { Investigation and } \\
\text { safeguarding of forests }\end{array}$ & $\begin{array}{l}\text { Completion of the handling of new cases } \\
\text { of forestry crimes (illegal logging, illegal } \\
\text { mining and fire) at least by } 75 \%\end{array}$ & $\begin{array}{l}\text { Development of Forest } \\
\text { Safeguarding Facilities and } \\
\text { Infrastructure }\end{array}$ \\
\hline
\end{tabular}

Source: Regulation of the Minister of Forestry, 2011, Perpres, 2011 
Table 8: Use of DAK Forestry of 2012

\begin{tabular}{|c|c|c|}
\hline No & Use & Activity/Target \\
\hline 1 & $\begin{array}{l}\text { Development of } \mathrm{KPH} \\
\text { Operational Facilities and } \\
\text { Infrastructure }\end{array}$ & $\begin{array}{l}\text { Implemented in accordance with the needs and budget availability by } \\
\text { referring to the standard, guidelines and technical guidelines on the } \\
\text { implementation of activities. Among others: GPS, forest inventory } \\
\text { equipment and mapping equipment. }\end{array}$ \\
\hline 2 & $\begin{array}{l}\text { Rehabilitation of critical } \\
\text { land in River Basins } \\
\text { Rehabilitation of Swamp, } \\
\text { Peatland, Mangrove and } \\
\text { Coastal Forests }\end{array}$ & $\begin{array}{l}\text { Reforestation and vegetative enrichment, Land rehabilitation and } \\
\text { vegetative enrichment, Rehabilitation of Swamp/Peatland/Mangrove } \\
\text { and Coastal areas, }\end{array}$ \\
\hline 3 & $\begin{array}{l}\text { Development of Forest } \\
\text { Safeguarding Facilities and } \\
\text { Infrastructure }\end{array}$ & $\begin{array}{l}\text { Implemented in accordance with the needs and budget availability by } \\
\text { referring to the standard, guidelines and technical guidelines on the } \\
\text { implementation of activities. Procurement of forest facilities and } \\
\text { infrastructure in the form of motorbikes, guard posts, GPS, } \\
\text { communication equipment }\end{array}$ \\
\hline
\end{tabular}

Source: Regulation of the Minister of Forestry, 2012

DAK Forestry of 2013: The allocation of DAK Forestry for fiscal year 2013 was based on Regulation of the Minister of Forestry Number: P.47/Menhut-II/2012 regarding Technical Guidelines on the Use of Specific Allocation Fund for the Forestry Sector in Fiscal Year 2013. Pursuant to the aforementioned regulation, DAK Forestry of 2013 was to be used for the following activities:

a) Rehabilitation of Protected Forest and critical land outside Forest Areas, Mangrove and Coastal Forests, Forest Conservation Parks and City Forests. For provinces/regency/city having damaged mangrove forests, DAK Forestry program were to be prioritized for the rehabilitation of mangrove forests;

b) Management of Forest Conservation Parks and City Forests including Forest Safeguarding;

c) Maintenance of plants resulting from rehabilitation in the preceding years;

d) Construction and Maintenance of Technical Civil Structures (Land and Water Conservation Structures) including Controlling DAM, Restraining DAM, Gully Plug, Absorption Well, Ponds and other Land and Water Conservation Structures;

e) Enhancement of the Procurement of Forest Safeguarding Facilities and Infrastructure;

f) Development of Forestry Counseling Facilities and Infrastructure;

g) Development of KPH Operational Facilities and Infrastructure.

Table 9: Intersection of Activities and Programs between Presidential Regulation and DAK Forestry of 2013

\begin{tabular}{|c|c|c|c|}
\hline No & $\begin{array}{ll}\text { Action Plan in } \\
\text { Presidential Regulation }\end{array}$ & Activity/Target & DAK Forestry \\
\hline 1 & $\begin{array}{l}\text { Development of Forest } \\
\text { Management Unit }(\mathrm{KPH})\end{array}$ & Establishment of $120 \mathrm{KPH}$ & $\begin{array}{l}\text { Development of KPH } \\
\text { Operational Facilities and } \\
\text { Infrastructure }\end{array}$ \\
\hline 2 & $\begin{array}{l}\text { Investigation and } \\
\text { safeguarding of forests }\end{array}$ & $\begin{array}{l}\text { Completion of the handling of new cases } \\
\text { of forestry crimes (illegal logging, illegal } \\
\text { mining and fire) at least by } 75 \%\end{array}$ & $\begin{array}{l}\text { Development of Forest } \\
\text { Safeguarding Facilities } \\
\text { and Infrastructure }\end{array}$ \\
\hline
\end{tabular}

Source: Regulation of the Minister of Forestry, 2013, Perpres 61/2011

Unlike the allocations of DAK Forestry of 2010 up to 2012 in which there were still several intersecting programs, for the allocation of DAK Forestry of 2013 the government apparently started to focus on the physical development of forestry infrastructure, by also continuing various on-going programs and policies from 2010, such as: Enhancement of the Procurement of Forest Safeguarding Facilities and Infrastructure as well as Development of Forestry Counseling Facilities and Infrastructure. Financing for the development of $\mathrm{KPH}$ Operational Facilities and Infrastructure which was started as of DAK Forestry of 2012 was also 
continued. Therefore, further analysis revealed the interconnection between Presidential Regulation Number 61 of 2011 and DAK Forestry of 2013 as follows:

Table 10: Use of DAK Forestry of 2013

\begin{tabular}{|c|c|c|}
\hline No & Use & Activity/Target \\
\hline 1 & $\begin{array}{l}\text { Development of KPH } \\
\text { Operational Facilities and } \\
\text { Infrastructure }\end{array}$ & $\begin{array}{l}\text { Implemented in accordance with the needs and budget availability by } \\
\text { referring to the standard, guidelines and technical guidelines on the } \\
\text { implementation of activities. Among others: GPS, forest inventory } \\
\text { equipment and mapping equipment. }\end{array}$ \\
\hline 2 & $\begin{array}{l}\text { Development of Forest } \\
\text { Safeguarding Facilities } \\
\text { and Infrastructure }\end{array}$ & $\begin{array}{l}\text { Implemented in accordance with the needs and budget availability by } \\
\text { referring to the standard, guidelines and technical guidelines on the } \\
\text { implementation of activities. Procurement of forest facilities and } \\
\text { infrastructure in the form of motorbikes, guard posts, GPS, } \\
\text { communication equipment }\end{array}$ \\
\hline
\end{tabular}

Source: Regulation of the Minister of Forestry, 2013

DAK Forestry of 2014: The allocation of DAK Forestry for fiscal year 2014 was based on Regulation of the Minister of Forestry Number: P.67/Menhut-II/2013 regarding Technical Guidelines on the Use of Specific Allocation Fund for the Forestry Sector in Fiscal Year 2014. Pursuant to the aforementioned regulation, DAK Forestry of 2014 was to be used for the following activities:

a) Acceleration of the Development and Operation of KPH;

b) Rehabilitation of Forest and Land Within and Outside Forest Areas;

c) Improvement of Forest Protection and Safeguarding;

d) Improvement of the Management of Forest Conservation Parks;

e) Improvement of Forestry Counseling;

f) Improvement of Group-based Forest Product Processing;

g) Improvement of the Management of Essential Ecosystem Areas.

Unlike the allocation of DAK Forestry of 2013, the allocation of DAK Forestry of 2014 was not too focused on the development physical infrastructure. However, there were several additional focuses of policy related to group-based forest product processing and the improvement of essential ecosystem areas. The interconnection between Presidential Regulation Number 61 of 2011 and DAK Forestry of 2014 in detail is as follows;

Table 11: Intersection of Activities and Programs between Presidential Regulation and DAK Forestry of 2014

\begin{tabular}{clll}
\hline No & $\begin{array}{l}\text { Action Plan in } \\
\text { Presidential Regulation }\end{array}$ & Activity/Target & DAK Forestry \\
\hline 1 & $\begin{array}{l}\text { Development of Forest } \\
\text { Management Unit (KPH) }\end{array}$ & Establishment of 120 KPH & $\begin{array}{l}\text { Development of KPH } \\
\text { Operational Facilities and } \\
\text { Infrastructure }\end{array}$ \\
2 & $\begin{array}{l}\text { Investigation and } \\
\text { safeguarding of forests }\end{array}$ & $\begin{array}{l}\text { Completion of the handling of new cases } \\
\text { of forestry crimes (illegal logging, illegal } \\
\text { mining and fire) at least by 75\% }\end{array}$ & $\begin{array}{l}\text { Development of Forest } \\
\text { Safeguarding Facilities and } \\
\text { Infrastructure }\end{array}$
\end{tabular}

Source: Regulation of the Minister of Forestry, 2013, Perpres 61/2011 
Table 12: Use of DAK Forestry of 2014

\begin{tabular}{llrl}
\hline No & Use & Activity/Target \\
\hline 1 & $\begin{array}{l}\text { Development of KPH } \\
\text { Operational Facilities and } \\
\text { Infrastructure }\end{array}$ & $\begin{array}{l}\text { Implemented in accordance with the needs and budget availability by } \\
\text { referring to the standard, guidelines and technical guidelines on the } \\
\text { implementation of activities. Among others: GPS, forest inventory } \\
\text { equipment and mapping equipment. }\end{array}$ \\
2 Development of Forest \\
$\begin{array}{l}\text { Safeguarding Facilities and } \\
\text { Infrastructure }\end{array}$ & $\begin{array}{l}\text { Implemented in accordance with the needs and budget availability by } \\
\text { referring to the standard, guidelines and technical guidelines on the } \\
\text { implementation of activities. Procurement of forest facilities and } \\
\text { infrastructure in the form of motorbikes, guard posts, GPS, } \\
\text { communication equipment }\end{array}$ \\
\hline
\end{tabular}

Source: Regulation of the Minister of Forestry, 2013

\section{Conclusion}

Based on the description above, it can be concluded that the forestry sector plays a very significant role in the endeavors to reduce GHG emission at the national and regional levels. The government has had actual commitment to reduce GHG emission by $26 \%$ with their own budget and $41 \%$ with international financial assistance, which had been regulated in Presidential Regulation Number 61 of 2011 regarding National/Regional Action Plan (RAN/RAD) regarding the Reduction of GHG Emission. Pursuant to the aforementioned regulation, the forestry sector is deemed as one of the largest contributors to GHG emission. Furthermore, there is also mandatory financing from the State/Regional Budget and other sources by virtue of applicable laws and regulations. In the budgeting mechanism of the State Budget for Regional Governments, there has been a mechanism of Specific Allocation Fund (DAK) covering 19 sectors, including Forestry. Despite the relatively small amount, the allocation for DAK Forestry has been continuously increasing, ranging from Rp250 billion to Rp550 billion. Unfortunately, the allocation for DAK Forestry is philosophically more prioritized for reforestation or tree replanting programs. The allocation for DAK Forestry has not been prioritized for regions having high level of forest conservation. As a consequence, some parties consider that the mechanism of DAK Forestry provides in incentive for regions to conduct deforestation and forest degradation in order to obtain larger allocations.

Based on the results of the analysis, it is known that the use of DAK Forestry from 2010 to 2014 has been significantly in conformity with programs for supporting the endeavors for reducing GHG emission set forth in Presidential Regulation Number 61 of 2011. This has certainly been conducted with due observance of the delegation of authorities to Regional Governments. The program that has always been financed by DAK Forestry and in support of Presidential Regulation Number 61 of 2011 is the development of forest safeguarding facilities and infrastructure. Whereas the other programs have been seeing fluctuations in terms of fund allocation. As of the allocation of DAK Forestry in 2012, the KPH operational facilities and infrastructure development program has been increasingly prioritized in the fund allocation for DAK Forestry.

Recommendations: In the future, several prerequisites and conditions that have been established must be continuously enhanced, especially in terms of harmony of programs or the amount of fund allocation. It is necessary to note that Presidential Regulation Number 61 of 2011 is in pure domain of public financing through the State/Regional Budget. Financing from the State Budget is certainly an obligation of Ministries/Government Agencies implemented through annual budgeting. By mapping the programs and activities set forth in Presidential Regulation Number 61 of 2011 to be financed by DAK Forestry, it is expected that there will not be any overlapping financing mechanisms. Financing from Ministries/Government Agencies should be allocated for activities that in fact constitute the Duties and Functions of the Central Government, whereas DAK Forestry fund should be used for financing the implementation of authorities that have already been delegated to regional governments. Expanding the scope of priorities covered by DAK Forestry should also be taken into consideration in order to provide better 
support for conservation efforts that have already been made in several regions. The solution offered here is to divide DAK Forestry into DAK Forestry for existing activities and DAK Forestry for conservation activities.

\section{References}

Ajani, J. I. (2013). Comprehensive Carbon Stock and Flow Accounting: A National Framework to Support Climate Change Mitigation Policy.

Astana, S., Sinaga, B. M., Soedomo, S. \& Simangunsong, C. H. (2012). Impact of Macroeconomic Policy and External Factors Against Deforestation and Forest Degradation Rate of Nature: A Case Study Deforestation To Expanding the Area of Food Crops and Plantation And Industrial Plantation Forest and Forest Degradation Natural Area of Concession. Journal of Forestry Policy Analysis, 9(3). December;

Diniyati, D. \& Awang, S. A. (2010). Determination Policy Forms Community Forestry Development Incentive Territory on the Mount Sawal, Ciamis: Study with AHP Method. Journal of Forestry Policy Analysis, 7(2). August;

Basic Document on Practical State Budget in Indonesia. (2014). Directorate General of Budget. Ministry of Finance;

Ekawati, S., Ginoga, K. L. \& Lugina, M. (2013). Condition for the Forest Governance Implementation of Reduced Emissions from Deforestation and Forest Degradation (REDD +) in Indonesia. Journal of Forestry Policy Analysis, 10(1). April.

Fitri, N., Indartik, \& Ginoga, K. L. (2011). Draft Analysis Role of the Parties and Distribution Mechanism The incentive In Reducing Emissions from Deforestation and Forest Degradation. Journal of Forestry Policy Analysis, 8(2). August.

Kartodihardjo, H. \& Jhamtani, H. (2006). Environmental Politics and Power in Indonesia. Equinox Publishing. Jakarta;

Resosudarmo, B. P. (2005). The Politics and Economics of Indonesia's Natural Resources. Pasir Panjang. ISEAS.

Riyanto, G. (2006). Order Politics and Policy Forest Management in Indonesia. Community Journal of Sociology, XIII(2). December.

Rickels, W. (2010). Method for Greenhouse Gas Offset Accounting; A Case Study of Ocean Iron Fertilization.

Setiono, B. (2013). Specific Allocation Fund for Forestry To Help Local Government Implement: Government Targets Reduce Carbon Emissions. Final Report BKF-AIPEG.

Siswiyanti, Y., Darusman, D., Kartodihardjo, H. \& Ichwandi, I. (2015). Prospects for Implementation of Convention on Climate Change in Forest Management Indonesia. Journal of Forestry Policy Analysis, 12(1). April.

Susiyanto, D. (2015). Fiscal Financing Options to Support Critical Land Use in Indonesia. Final Report BKFUKCCU.

Tambunan, P., Suhendi, H., Siswanto, B. E. \& Lisnawati, Y. (2011). Adaptation Management of Climate Change. Journal Forestry Policy Analysis, 9(1).

Wibowo, A. (2013). Study of Greenhouse Gas Emission Reduction Forest Sector Policy Support of Presidential Decree Number 61 Year 2011. Journal Forestry Policy Analysis, 10(3).

Wibowo, A. (2013). Application 2006 IPCC Guidelines for Greenhouse Gas Emissions Calculation Forestry in South Sumatra. Journal Forestry Policy Analysis, 10(2). 